Abstracta Iranica Abstracta Iranica

Revue bibliographique pour le domaine irano-aryen

Volume 24 | 2003

Comptes rendus des publications de 2001

\title{
Dāstān-hā-ye maḥbūb-e man, (gozīneš, naqd va barrasī). Tehrān, Našr-e Češme, 1380/2001, 512 p.
}

\section{Christophe Balaÿ}

\section{(2) OpenEdition}

1 Journals

\section{Édition électronique}

URL : http://journals.openedition.org/abstractairanica/34701

DOI : 10.4000/abstractairanica.34701

ISSN : 1961-960X

Éditeur :

CNRS (UMR 7528 Mondes iraniens et indiens), Éditions de l'IFRI

\section{Édition imprimée}

Date de publication : 15 mai 2003

ISSN : 0240-8910

Référence électronique

Christophe Balaÿ, "Dāstān-hā-ye maḥbūb-e man, (gozīneš, naqd va barrasī). Tehrān, Našr-e Češme, 1380/2001, 512 p. », Abstracta Iranica [En ligne], Volume 24 | 2003, document 239, mis en ligne le 05 janvier 2010, consulté le 25 septembre 2020. URL : http://journals.openedition.org/abstractairanica/ 34701 ; DOI : https://doi.org/10.4000/abstractairanica.34701

Ce document a été généré automatiquement le 25 septembre 2020.

Tous droits réservés 


\title{
Dāstān-hā-ye maḥbūb-e man, (gozīneš, naqd va barrasī). Tehrān, Našr-e Češme, 1380/2001, 512 p.
}

\author{
Christophe Balaÿ
}

1 'Alī-Ašraf Darvǐšiyān est un romancier connu et actif non seulement dans le domaine de l'écriture de la nouvelle et du roman mais aussi dans les recherches folkloriques. Il a déjà publié plusieurs recueils de contes, en particulier du Kurdistan dont il est originaire. A l'instar de nombreux autres écrivains de sa génération, il édite ici une trentaine de jeunes auteurs de la troisième génération plus quelques-uns de la sienne. Ce faisant, il permet à de jeunes nouvellistes de se faire connaître et de sortir du petit cercle des initiés. L'A. introduit ces trente textes par un essai d'une vingtaine de pages qui fait le point sur l'histoire des genres narratifs et l'évolution de la prose persane. On ne sera pas forcément d'accord avec toutes ses conclusions sur les origines du genre « nouvelle ». L'A. reprend sans trop les discuter des informations glanées ici et là (il cite la plupart de ses sources). Il déclare sa dette aux idées de Goldmann et de Lucaks, grâce aux traductions de Moḥammad-Ja'far Pūyande ainsi qu'aux articles de Moḥammad MoĤtārī. Il fait une description intéressante de la décennie 90 et de la troisième génération, génération instable, inquiète, mais avide d'expérience et lucide sur son destin; une génération d'écrivains qui savent établir le contact avec le lecteur, mais que les revues littéraires n'accueillent pas suffisamment. Les trente nouvelles de cette collection forment la première partie d'une série de 65 textes tirés de divers périodiques et publications entre 1370 et 1379 (1991-2000). L'auteur annonce un deuxième volume qui sera composé de nouvellistes de la première et de la deuxième générations (1921-1989). Chaque nouvelle est suivie d'une analyse littéraire de quelques pages. 
INDEX

Thèmes : 11.1.2. Littérature persane moderne

\section{AUTEURS}

CHRISTOPHE BALAŸ

IFRI/INALCO - Téhéran/Paris 